\title{
Pengaruh Volatilitas Nilai Tukar terhadap Volume Perdagangan Internasional di ASEAN-3
}

\author{
(The Effect of Exchange Rate Volatility on the Volume of International Trade in ASEAN-3) \\ Fatimatuz Zahroh, Zainuri*, Rafael Purtomo \\ Jurusan Ilmu Ekonomi Studi Pembangunan, Fakultas Ekonomi dan Bisnis, Universitas Jember (UNEJ) \\ Jln. Kalimantan 37, Jember 68121 \\ E-mail: zainuri.feb@unej.ac.id
}

\begin{abstract}
Abstrak
Penelitian ini bertujuan untuk mengetahui pengaruh volatilitas nilai tukar terhadap permintaan eksport di negara Kawasan ASEAN 3 yaitu Indonesia, Thailand dan Filipina. Dalam penelitian ini menggunakan metode Error Correction Model (ECM) Domawitz-Elbadawi untuk mengatahui bagaimana pengaruh variabel dependen terhadap variabel independen dalam jangka pendek maupun dalam jangka panjang. Data yang digunakan dalam penelitian ini merupakan data skunder yang meliputi data Nilai tukar, CPI (Consumer Price Index), FDI (Foreign Direct Investment) dan Eksport dari tahun 1997Q1-2016Q3. Hasil menunjukkan bahwa dalam jangka pendek volatilitas nilai tukar berpengaruh negatif dan signifikan terhadap permintaan eksport pada negara Indonesia sedangkan untuk negara Filipina dan Thailand Volatilitas nilai tukar berpengaruh negatif tetapi tidak signifikan. Dalam jangka panjang volatilitas nilai tukar berpengaruh negatif tetapi tidak signifikan terhadap permintaan eksport di negara Indonesia dan Thailand sedangkan di negara Filipina volatilitas nilai tukar berpengaruh positif dan signifikan terhadap permintaan eksport. Untuk memicu peningkatan ekspor di negara kawasan ASEAN 3 maka diperlukan kebijakan nilai tukar.
\end{abstract}

Kata Kunci: Nilai tukar, Export dan (ECM) Domawitz-Elbadawi.

\begin{abstract}
This study aims to determine the effect of exchange rate volatility on export demand in ASEAN 3 countries namely Indonesia, Thailand and the Philippines. In this research use Error Correction Model (ECM) Domawitz-Elbadawi method to know how dependent variable influence to independent variable in short term and in long term. The data used in this study is secondary data covering data exchange rate, CPI (Consumer Price Index), FDI (Foreig Direct Investment) and Export from 1997Q12016Q3. The results show that in the short run the exchange rate volatility has a negative and significant effect on export demand in the country of Indonesia while for the Philippines and Thailand the exchange rate volatility has a negative but insignificant effect. In the long term, exchange rate volatility has negative but not significant effect on export demand in Indonesia and Thailand, while in Philippine, exchange rate volatility has positive and significant effect on export demand. It shows the importance of exchange rate policy in improving Indonesia's export performance.
\end{abstract}

Keywords: Exchangerate, Export, and ECM) Domawitz-Elbadawi.

\section{Pendahuluan}

Sejak runtuhnya Sistem Bretton Woos pada tahun 1973 memicu terjadinya volatilitas nilai tukar di beberapa negara baik negara maju maupun di negara yang masih berkembang. Volatilitas nilai tukar mempunyai pengaruh yang bervariasi terhadap perekonomian suatu negara misal nilai tukar berpengaruh terhadap aktivitas perdagangan internasional. Dalam teori nilai tukar menyatakan bahwa saat nilai mata uang suatu negara terdepresiasi, maka akan meningkatkan permintaan ekspor sehingga menambah jumlah ekspor. Tetapi didalam beberapa penelitian menyatakan bahwa pengaruh volatilitas nilai tukar terhadap ekspor menyebabkan ketidakpastian tentang keuntungan yang diperoleh dalam kegiatan perdagangan internasional. Terdapat beberapa peneliti Tetapi Dalam beberapa penelitian menyatakan bahwa pengaruh dari volatilitas nilai tukar terhadap perdagangan internasional menyebabkan adanya ketidakpastian tentang keuntungan yang diperoleh, dan mengurangi volume perdagangan. terdapat beberapa temuan empiris yang mendukung adanya efek negatif volatilitas nilai tukar terhadap volume perdagangan, seperti penelitian yang dilakukan oleh (Auboin, 2013) bahwa volatilitas nilai tukar menyebabkan penurunan volume perdagangan internasional. Namun kesesuaian antara teori dengan kondisi rill mendapatkan penolakan dari beberpa penelitian. Studi empiris yang dilakukan oleh (Oskooee, 2007) menentang kondisi tersebut sebab menganggap bahwa volatilitas nilai tukar berdampak positif terhadap volume perdagangan internasional. Pernyataan tersebut dipertegas oleh Aminu et al., (2013) yang menyatakan bahwa untuk meningkatkan ekspor dan devisa, mata uang suatu negara harus terdepresiasi sehingga meningkatkan jumlah ekspor. Dengan demikian volatilitas nilai tukar dapat mempengaruhi jumlah ekspor di suatu negara.

Implikasi volatilitas nilai tukar dalam mempengaruhi permintaan eksport ditunjukkan dalam periode yang berbeda baik dalam jangka panjang maupun dalam jangka pendek. Hal ini sesuai dengan temuan empiris yang dilakukan oleh Asteriou, et al., (2016) dengan objek penelitian negara MINT( Meksiko, Indonesia, Nigeria dan Turki) menyebutkan bahwa dalam jangka panjang tidak ada hubungan antara volatilitas nilai tukar terhadap eksport Akan tetapi Dalam jangka pendek, ada hubungan yang signifikan dari volatilitas nilai tukar terhadap permintaan impor/ekspor. Namun, terjadi

\footnotetext{
* Corresponding author
} 
penolakan oleh beberapa penelitian. Studi empiris yang dilakukan oleh Arize et al., 2010 menganggap bahwa volatilitas nilai tukar mempengaruhi volume perdagangan internasional dalam jangka panjang di negara LDC. Pernyataan tersebut diperkuat oleh Doganlar, M., (2002) dengan objek penelitan di negra ASEAN menyatakan bahwa adanya pengaruh volatilitas nilai tukar terhadap volume perdagangan internasional dalam jangka panjang. Oleh karena itu melalui periode waktu volatilitas nilai tukar mempengaruhi volume perdagangan.Menghindari resiko penting untuk menentukan efek dari volatilitas nilai tukar pada permintaan eksport.

Jika eksportir sangat menghindari risiko, maka peningkatan volatilitas nilai tukar akan meningkatkan utilitas marjinal yang diharapkan dari pendapatan ekspor karena eksportir akan lebih memilih untuk memproduksi lebih banyak untuk menghindari penurunan pendapatan ekspor.Namun,eksportir yang rendah dalam menghindari risiko akan lebih memilih untuk mengurangi ekspor karena peningkatan volatilitas nilai tukar lebih tinggi dapat mengurangi utilitas marginal yang diharapkan dari pendapatan ekspor De Grauwe (1988). Pendapat tersebut juga didukung oleh Hall. S et al 2010 dengan objek penelitian negara emerging market bahwa volatilitas nilai tukar dapat mengurangi jumlah ekspor bagi negara-negara tersebut. Hal ini dikarenakan produsen di negara-negara umumnya menghindari risiko. Dengan kata lain, peningkatan volatilitas nilai tukar akan meningkatkan ketidakpastian tentang perilaku perilaku masa depan nilai tukar yang berdampak pada perdagangan. Oleh karena itu, eksportir akan lebih memilih untuk menjual di pasar domestik daripada menjualnya di pasar luar negeri yang dapat menyebabkan kerugian. Para eksportir lebih memilih menjual dipasar domestik daripada menjualnya di pasar luar negeri dikarenakan Volatilitas nilai tukar yang lebih tinggi menyebabkan ketidakpastian biaya yang dikeluarka Asteriou, et al., (2016). Hal ini dikarenakan biayakeseluruhan disepakati pada saat kontrak perdagangan, bukan pada saat proses transaksi. Apabila disaat kontrak perdagagan nilai kurs sama sampai proses transaksi maka biaya yang dikeluarkan sesuai, tetapi apabila nilai kurs pada saat proses pengiriman lebih tinggi maka menyebabkan biaya yang dikeluarkan lebih tinggi sehingga mengurangi manfaat dari perdagangan internasional.

Dalam beberapa teori, Nilai tukar diartikan sebagai harga mata uang luar negeridalam satuan uang domestic. Nilai tukar merupakan perbandingan antar mata uang negara satu dengan negara lain. Nilai tukar mata uang suatu negara dibedakan atas nilai tukar nominal dan nilai tukar rill.Nilai tukar nominal merupakan harga relatif mata uang dua negara. Sedangkan nilai tukar rill menyatakan tingkat,dimana pelaku ekonomi dapat memperdagangkan barang-barang dari suatu negara untuk barang-barang dari negara lain. Nilai tukar rill diantara mata uang kedua negara dihitung dari nilai tukar nominal dikalikan dengan rasio tingkat harga yang ada dikedua tersebut.Hubungan nilai tukar nominal dapat diformulasikan sebagai berikut (Mankiw, 2003:127).

REER - ER FP / DP

Dimana:

REER $=$ Real Effective Exchange Rate ( Nilai Tukar Rill)

$\mathrm{ER}=$ Exchange rate nominal yang dapat dinyatakan dalam directterm (mata uang domestik/ 1 dollar ) maupun indirectterm(dollar/ 1 mata uang domestik)

$\mathrm{FP}=$ Foreign Price (Indeks harga luarnegeri)

$\mathrm{DP}=$ Domestic Price (Indeks harga domestik)

Dari formulasi diatas dapat dijelaskan bahwa daya saing perdagangan luar negeri ditentukan oleh dua hal yaitu ER dan rasio harga kedua negara. Jika ER (direct term) meningkat (terapresiasi), dengan rasio harga konstan, maka ada hubungan positif dengan neraca perdagangan. Hal ini disebabkan ER yang lebih tinggi akan memberikan indikasi rendahnya harga produk domestik relatif terhadap harga produk lain. Sebaliknya dengan asumsi kurs tidak fluktuatif, maka daya saing sangat ditentukan oleh kemampuan negara atau otoritas moneter dalam mengendalikan laju harga dengan dengan berbagai instrumen yang menjadi kewenanganya.

Sehingga dengan melihat permasalahan diatas terdapat rumusan masalah ayaitu bagaimana pengaruh nilai tukar terhadap permintan eksport. Tujuan dari penelitian ini untuk mengetahui bagaimana pengaruh volatilitas nilai tukar terhadap permintaan eksport.

\section{Metode}

\section{Rancangan atau Desain Penelitian}

Penelitian yang digunakan yaitu analisis statistik deskriptif dimana dalam penelitian ini nantinya digunakan untuk menganalisis data yang telah terkumpul.

\section{Jenis dan Sumber Data}

Jenis data yang digunakan dalam artikel ini adalah data sekunder yang berupa data time series dengan bentuk quartalan dalam periode 1997Q1- 2016 Q3. Pemilihan rentan waktu didasari dengan fenomena-fenomena yang terjadi seperti saat terjadinya krisis ekonomi pada tahun 1997 dan tahun 2008. Sedangkan untuk sumber data diperoleh dari International Monetary Funds (IMF), dan World bank. Penelitian menggunakan obyek 3 Negara di Kawasan ASEAN 3 yaitu Indonesia, Thailand dan Filipina. Alasan menggunakan ketiga negara tersebut dikarenakan menganut rezim nilai tukar yang sama yaitu yaitu Free Floatingyang berarti ketiga negara tersebut menyerahkan pergerakan nilai tukar pada permintaan dan penawaran di pasar valas.

\section{Populasi dan Sampel}

Populasi dalam penelitian ini mencakup data nilai tukar. FDI,CPI dan eksport di negara Kawasan ASEAN 3 yaitu Indonesia, Thailand dan Filipina pada tahun 1997Q12016 Q3.

\section{Metode Analisis Data}

Metode yang digunakan dalam penelitian ini yaitu Error Correction Model (ECM). Metode ECM untuk mengidentifikasi hubungan jangka panjang dan jangka pendek yang terjadi karena adanya kointegrasi diantara variabel penelitian. Dalam penelitian ini menggunakan model ECM dari Dormowitz dan Elbadawi model ini didasarkan pada kenyataan bahwa perekonomian berada dalam kondisi ketidakseimbangan. Model ECM ini juga mengasumsikan bahwa para agen ekonomi akan selalu menemukan bahwa apa yang direncanakan tidak selalu sama dengan realita yang ada. Adapun spesifikasi model penelitian ini berdasarkan 
pada penelitian yang dilakukan oleh De Vita,G. Dan Abbott. A. (2004a).

$\mathrm{X}_{\mathrm{t}}=\beta_{0}+\beta_{1} \mathrm{CPI}_{\mathrm{t}}+\beta_{2} \mathrm{REER}_{\mathrm{t}}+\beta_{3} \mathrm{FDI}_{\mathrm{t}}+\varepsilon_{\mathrm{t}} \ldots$ (1)

Dimana:

$\mathrm{X}=$ Eksport, $\mathrm{CPI}=$ Consumer Price Index

$\mathrm{REER}=$ Nilai tukar rill, FDI $=$ Foreign Direct Investment,

$\beta_{0}=$ Konstanta, $\beta, 1,2,3=$ Parameter,$\varepsilon=$ Error Term

Kemudian diklakukan parametirasi persamaan (1) menjadi bentuk ECM sebagai berikut:

$\Delta \mathrm{X}_{\mathrm{t}}=\beta_{0}+\beta_{1} \Delta \mathrm{CPI}_{\mathrm{t}}+\beta_{2} \Delta \mathrm{REER}_{\mathrm{t}}+\beta_{3} \Delta \mathrm{FDI}_{\mathrm{t}}+\beta_{4}$

$\mathrm{CPI}_{\mathrm{t}-1}+\beta_{5} \mathrm{REER}_{\mathrm{t}-1}+\beta_{6} \mathrm{FDI}_{\mathrm{t}-1}+\beta_{7} \mathrm{EC}_{\mathrm{t}-1}+\varepsilon_{\mathrm{t}} \ldots$

Dimana $\mathrm{EC}_{\mathrm{t}}=\mathrm{CPI}_{\mathrm{t}-1}+\mathrm{REER}_{\mathrm{t}-1}+\mathrm{FDI}_{\mathrm{t}}-\mathrm{X}_{\mathrm{t}-1}$.

\section{Hasil dan Pembahasan}

\section{Hasil}

Berikut inilah hasil dari analisis statistik deskriptif dari variabel yang digunakan dalam penelitian ini di negara kawasan ASEAN 3

a. Uji akar Unit

Tabel 1. Hasil dari Uji akar unit (Unit root test) di Negara ASEAN 3

\begin{tabular}{lcrrr}
\hline Indonesia & $\mathrm{X}$ & $\mathrm{CPI}$ & $\mathrm{REER}$ & $\mathrm{FDI}$ \\
\hline Level & -3.229729 & 0.223459 & -3.204537 & -1.190151 \\
& -2.899115 & -2.899115 & -2.899115 & -2.900137 \\
$1^{\text {st }}$ Difference & -10.93798 & -6.794950 & -8.327082 & -7.949671 \\
\hline Thailand & -2.899619 & -2.899619 & -2.899619 & -2.900670 \\
\hline Level & $\mathrm{X}$ & $\mathrm{CPI}$ & $\mathrm{REER}$ & $\mathrm{FDI}$ \\
& -3.467067 & -0.851291 & -2.828227 & -5.410318 \\
$1^{\text {st }}$ Difference & -2.899115 & -2.900137 & -2.899115 & -2.899115 \\
\hline Filipina & -2.899619 & -2.900137 & -2.899619 & -2.900670 \\
\hline Level & $\mathrm{X}$ & $\mathrm{CPI}$ & $\mathrm{REER}$ & $\mathrm{FDI}$ \\
& -0.539250 & -3.421101 & -10.21970 & -7.296764 \\
$1^{\text {st }}$ Difference & -2.900137 & -2.899115 & -2.899619 & -2.899115 \\
\hline
\end{tabular}

Sumber: Data diolah, 2016.

Dari Tabel 1 menunjukkan bahwa semua variabel stationer pada tingkat $1^{\text {st }}$ Difference. Data dikatakan stationer apabila nilai t-statistik lebih besar dari nilai kritis $(\alpha=5 \%)$.

b. Uji kointegrasi

Tabel 2. Hasil Kointegrasi di Negara ASEAN 3

\begin{tabular}{lllll}
\hline Negara & Keterangan & $\begin{array}{l}\text { Trace } \\
\text { Statistic }\end{array}$ & $\begin{array}{l}\text { Nilai } \\
\text { Kritis (5\%) }\end{array}$ & Keterangan \\
\hline Indonesia & Trace & 172.7854 & 47.85613 & \\
& Max Eigen & & 27.58434 & Terkointegrasi \\
& & 47.85613 & & \\
Filipina & Trace & 147.1790 & 47.85613 & \\
& & 62.01883 & 27.58434 & Terkointegrasi \\
& Max Eigen & & & \\
Thailand & Trace & 204.1108 & 47.85613 & \\
& Max Eigen & 88.49893 & 27.58434 & Terkointegrasi \\
\hline
\end{tabular}

Sumber: Data diolah, 2016

Dari Tabel 2 menunjukkan bahwa semua variabel terkointegrasi. Dengan melihat nilai trace statistic lebih besar dari nilai kritis yang berarti antar variabel mempunyai hubungan dalam jangka panjang.

c. Hasil ECM jangka pendek di negara ASEAN 3.

Tabel 3. ECM jangka pendek di Indonesia

\begin{tabular}{lcc}
\hline \multirow{2}{*}{ Variabel } & \multicolumn{2}{c}{ Eksport } \\
\cline { 2 - 3 } & t-statistik & probabilitas \\
\hline C & -0.885211 & 0.3792 \\
DCPI & 0.089830 & 0.9287 \\
DREER & 0.997983 & 0.0219 \\
DFDI & 2.419813 & 0.0297 \\
\hline
\end{tabular}

Sumber: Data diolah, 2016

Tabel 3 menunujukkan bahwa menuujukkan variabel nilai tukar berpengaruh negatif dan signifikan terhadap permintaan eksport. Sedangkan variabel FDI berpengaruh positif dan signifikan terhadap prmintaan eksport dan variabel CPI berpengruh negatif tetapi tidak signifikan terhadap permintaan Hasil estimasi jangka pendek menunjukkan bahwa nilai yang berpengaruh signifikan adalah apabila nilai probabilitas Variabel CPI, variabel nilai tukar dan variabel FDI lebih kecil dari nilai $\alpha(5 \%)$.

Tabel 4. ECM jangka pendek di Thailand

\begin{tabular}{lcc}
\hline \multirow{2}{*}{ Variabel } & \multicolumn{2}{c}{ Eksport } \\
\cline { 2 - 3 } & t-statistik & Probabilitas \\
\hline $\mathrm{C}$ & -2.060237 & 0.0433 \\
DCPI & 0.856699 & 0.3947 \\
DREER & 0.551906 & 0.5828 \\
DFDI & 2.376908 & 0.0312 \\
\hline
\end{tabular}

Sumber: Data diolah, 2016

Tabel 4 menunujukkan bahwa menuujukkan variabel nilai tukar berpengaruh negatif dan tetapi tidak signifikan terhadap permintaan eksport.Sedangkan variabel FDI berpengaruh positif dan signifikan terhadap prmintaan eksport dan variabel CPI berpengruh negatif tetapi tidak signifikan terhadap permintaan eksport. Hasil estimasi jangka pendek menunjukkan bahwa nilai yang berpengaruh signifikan adalah apabila nilai probabilitas Variabel CPI, variabel nilai tukar dan variabel FDI lebih kecil dari nilai $\alpha(5 \%)$.

Tabel 5. ECM jangka pendek di Filipina

\begin{tabular}{lcc}
\hline \multirow{2}{*}{ Variabel } & \multicolumn{2}{c}{ Eksport } \\
\cline { 2 - 3 } & t-statistik & Probabilitas \\
\hline C & 0.230281 & 0.8186 \\
DCPI & 0.847470 & 0.3998 \\
DREER & 1.313498 & 0.1935 \\
DFDI & -1.757875 & 0.0833 \\
\hline
\end{tabular}

Sumber: Data diolah, 2016

Tabel 5 menunujukkan bahwa menuujukkan variabel nilai tukar, CPI, dan FDI berpengaruh negatif tetapi tidak signifikan terhadap permintaan eksport. Hasil estimasi jangka pendek menunjukkan bahwa nilai yang berpengaruh signifikan adalah apabila nilai probabilitas Variabel CPI, variabel nilai tukar dan variabel FDI lebih kecil dari nilai $\alpha$ $(5 \%)$.

\section{d. Hasil Uji Asumsi Klasik}

Dari Tabel 6 menunjukkan bahwa semua variabel di negara Kawasan ASEAN 3 tidak terkena multikol,dan Heteroskedasitas. Sedangkan untuk negara Thailand dan 
Filipina terjadi Autokorelasi.

Tabel 6. Hasil Uji Asumsi Klasik di negara Kawasan ASEAN 3

\begin{tabular}{|c|c|c|c|}
\hline Asumsi Klasik & Indonesia & Thailand & Filipina \\
\hline Multikolienaritas & Tidak ada & Tidak ada & $\begin{array}{l}\text { Tidak } \\
\text { ada }\end{array}$ \\
\hline Autokorelasi & Tidak ada & $\begin{array}{l}\text { Terjadi } \\
\text { Auto }\end{array}$ & $\begin{array}{l}\text { Terjadi } \\
\text { Auto }\end{array}$ \\
\hline Heteroskedasitas & Tidak ada & Tidak ada & $\begin{array}{l}\text { Tidak } \\
\text { ada }\end{array}$ \\
\hline Normalitas & Normal & Normal & $\begin{array}{l}\text { Tidak } \\
\text { normal }\end{array}$ \\
\hline
\end{tabular}

Sumber; Data diolah (2016)

e. Hasil ECM jangka Panjang di Negara ASEAN 3

Tabel 7. ECM jangka pendek di Indonesia

\begin{tabular}{lcc}
\hline \multirow{2}{*}{ Variabel } & \multicolumn{2}{c}{ Eksport } \\
\cline { 2 - 3 } & t-statistk & Probabilitas \\
\hline CPI & 13.99067 & 0.2972 \\
REER & -01.107490 & 0.5110 \\
FDI & $2.36 \mathrm{E}-07$ & 0.0000 \\
\hline
\end{tabular}

Sumber; Data diolah. (2016)

Dari tabel 7 menunjukkan bahwa variabel CPI berpengaruh positif tetapi signifikan, sedangkan untk variabel nilai tukar berpengaruh negatif dan variabel FDI berpengaruh positif dan signifikan terhadap permintaan eksport.

Tabel 8. ECM jangka pendek di Thailand

\begin{tabular}{lcc}
\hline \multirow{2}{*}{ Variabel } & \multicolumn{2}{c}{ Eksport } \\
\cline { 2 - 3 } & t-statistk & Probabilitas \\
\hline CPI & 2.319241 & 0.0231 \\
REER & 0.037370 & 0.9703 \\
FDI & -0.062029 & 0.9507 \\
\hline
\end{tabular}

Sumber ; Data diolah. (2016)

Dari Tabel 8 menunjukkan bahwa variabel CPI berpengruh positif dan signifikan terhadp permintaan eksport. Sedangkan untk variabel FDI dan nilai tukar berpengaruh negatif tetpi tidak signifikan.

Tabel 9. ECM jangka pendek di Filipina

\begin{tabular}{lcc}
\hline \multirow{2}{*}{ Variabel } & \multicolumn{2}{c}{ Eksport } \\
\cline { 2 - 3 } & t-statistk & Probabilitas \\
\hline CPI & 0.072520 & 0.0340 \\
\hline REER & 6.420019 & 0.0000 \\
\hline FDI & 0.319466 & 0.7503 \\
\hline
\end{tabular}

Sumber ; Data diolah. (2016)

Dari Tabel 9 menunjukkan bahwa variabel CPI berpengruh negatif dan signifikan terhadp permintaan eksport. Sedangkan untk variabel FDI berpengaruh negatif tidak signifikan terhadap permintaan eksport sedangan untuk variabel nilai tukar positif dn signifikan terhadp permintaan eksport.

\section{Pembahasan}

\section{Pengaruh volatilitas nlai tukar erhadap eksport}

Volatilitas nilai tukar merupakan fluktuasi kurs mata uang suatu negara terhadap mata uang negara lain. Krisis keuangan pada tahun 1997 dan 2008 menyebabkan terdepresiasinya mata uang di negara Kawasan ASEAN 3 yaitu Indonesia,
Thailand dan Filipina sehingga mengalami penurunan jumlah eksport di negara Kawasan ASEAN 3.

Berdasarkan hasil estimasi metode ECM di Indonesia pada jangka panjang dan jangka pendek diperoleh hasil bahwa variabel nilai tukar berpengaruh negatif dan signifikan terhadap volume perdagangan internasional. sejalan dengan Vitan (2004) dan Ginting (2013) yang menjelaskan bahwa volatilitas nilai tukar mempunyai efek yang negatif dan signifikan terhadap eksport dalam jangka pendek maupun jangka panjang. Hasil estimasi di Negaa Thailand menunjukkan bahwa tidak ada pengaruh volatilitas nilai tukar terhadap volume perdagangan Internasional. Hal ini sejalan dengan Asteiou (2016) dan Hayakawa et al 2009 yang menunjukkan bahwa dalam jangka panjang tidak ada hubungan antara volatilitas nilai tukar terhadap permintaan eksport dan import. Sedangkan hasil estimasi di Negara Filipina menunjukkan bahwa dalam jangka pendek tidak ada pengaruh volatilitas nilai tukar terhadap volume perdagangan internasional, sedangkan dalam jangka panjang volatilitas nilai tukar berpengrauh positif dan signifikan terhadap Volume peragangan internasional hal ini sejalan dengan temuan Oskooe ( 2007 ) yang menjelaskan bahwa volatilitas nilai tukar berpengaruh positif dan signifikan terhadap Volume perdagangan internasional dikarenakan ada beberapa pengeksport yang lebih berani mengambil resiko dengan memproduksi atau mengeksport dengan jumlah yang banyak meskipun nilai tukar sering berfluktuasi selain itu sebuah perusahaan mungkin mendapatkan keuntungan dari peningkatan volatilitas nilai tukar hal ini diperkuat oleh De Garuwe (1998).

Selain Volatilitas nilai tukar volume perdagangan internasional juga dipengaruhi oleh variabel independen lain seperti FDI dan CPI. Variabel FDI pada negara Filipina berpengaruh terhadap perdagangan, semakin tinggi FDI maka akan semakin meningkatkan jumlah eksport hal ini sejalan dengan Safitriani (2013) menyatakan bahwa FDI memberikan dampak jangka panjang yang positif terhadap ekspor, dikarenakan FDI merupakan investasi yang bersifat jangka panjang sehingga akan berpengaruh positif dengan meningkatkan jumlah ekspor. Sementara dalam jangka pendek FDI berdampak negatif terhadap ekspor.

Namun dalam hal impor ditemukan bahwa FDI berdampak negatif terhadap ekspor. Sedangkan di Negara Thailand dalam jangka pendek FDI berpengaruh negatif dan signifikan terhadap perdagangan internasional hal ini dikarenakan pada tahun 1997 terjadi krisis di Thailand yang menyebabkan para investor menarik semua modal yang ada di Thailand .

Dalam jangka panjang FDI tidak berpengaruh terhadap perdagangan Internasional di negara Thailand. FDI berpengaruh positif dan signifikan terhadap volume perdagangan internasional di Negara Indonesia sejalan dengan Mayang et al 2007 yang menyatakan bahwa FDI berdampak positif terhadap eksport akan tetapi dalam jangka panjang FDI berpengaruh positif dan tidak signifikan dikarenakan di Indonesia oleh orientasi FDI yang masuk ke Indonesia masih cenderung bersifat domestik Kholis (2012).

\section{Simpulan}

Dalam jangka pendek di temuikan adanya pengaruh negative dan signifikan Nilai tukar terhadap eksport di 
IndonesiadanThailand. Untuk Variabel FDI ditemukan adanya pengaruh positif dan signifikan di negara Indonesia, untuk negara Thailand variabel FDI mempunyai pengaruh negative dan signifikan terhadap eksport, dan untuk variabel CPI tidak berpengaruh terhadap eksport di Negara Kawasan ASEAN 3. Sedangkan pada negara Thailand variable nilai tukar, FDI dan CPI tidak berpengaruh terhadap eksport.

Dalam jangka panjang di negara Kawasan ASEAN 3 ditemukan bahwa terjadi hubungan negatif tetapi tidak signifikan antara nilai tukar terhadape ksport di Indonesia dan Thailand, sedangkan di Filipina ada pengaruh positif dan signifikan anatara nilai tukar terhadap eksport. Variabel CPI berpengaaruh positif tetapi tidak signifikan terhadap eksport di negara Indonesia, sedangkan di negara Filipina CPI berpengaruh negative dan signifikan terhadap eksport dan untuk negara Thailand variabel CPI berpengaruh negative tetapi tidak signifikan. Sedangkan untuk variabel FDI ditemukan adanya pengaruh negative tetapi tidak signifikan terhadap ekspor di negara Thailand dan Filipina, sedangkan untuk Negara Indonesia ada pengaruh positif tetapi tidak signifikan antara FDI terhadap eksport.

\section{Referensi}

Asteriou A.,Masatci K., \& Pilbeam K.,2016. Exchange rate volatility and international trade: International evidence from the MINT countries: Elsevier Economic Modelling. Vol. 58 hlm 133-140

Auboin, A., Ruta, M., 2013. The Relationship between Exchange Rates and International Trade: A Literature Review. Vol.12 hlm 577-605

Arize, A.C., (2010). Exchange-Rate Volatility and Foreign Trade: Evidence from Thirteen LDC's, Source: Journal of Business \& Economic Statistics, Vol. 18, No. 1
Bank Indonesia. 2009. Laporan Perekonomian tahunan www.bi.go.id. Diakses pada 20 Mei 2107

De Grauwe, P. (1988), "Exchange Rate Variability and the Slowdown in Growth of InternationalTrade," IMF Staff Papers, 35, 63-84

De Vita, G. and Abbott, A. (2004b), "Real exchange rate volatility and US exports: anARDLbounds testing approach", Economic Issues, Vol. 9, Pt 1, pp. 69-78

Donganlar,M. 2002. Estimating the impact of exchange rate volatilityon exports: evidence from Asian countries evidencen from Asian countries, Applied Economics Letters, 9:13, 859-863

Ginting. A.M, 2003. The Influence of Exchange Rate on Indonesia's Exports: Pusat Pengkajian, Pengolahan Data dan Informasi

Gujarati, D. (2003). Basic Econometrics Third \& Fourth edition. New York: McGraw-Hill

Oskooee, B.M, Hegerty, S.W.,2007. Exchange rate Volatility and trade Flows: a review article. J.Econ. Stud 34(3),211-25

Hall, S. et al. (2010). Exchange Rate Volatility and Export Performance: Do Emerging Market Economies Resemble Industrial Countries or other Developing Countries.

Hayakawa. K, Fukunari dan Kimura 2009. The effect of exchange rate volatility on international tradein East Asia; Journal of The Japanese and International Economics

Kholis 2012. Dampak Foreign Direct Investment Terhadap Pertumbuhan Ekonomi Indonesia. Studi Makroekonomi dengan Penerapan Data Panel. Jurnal Organisasi dan Manajemen, Volume 8, Nomor 2,

Mayang, Rakesh dan Nigel. 2007. Foreign Direct Investment and Int Ernational Trade. Source: Journal of Business \& Economic Statistics

Safitriani.S,2014. Perdagangan Internasional dan Foreign Direct Investmen di Indonesia: Badan Pusat Statistik

Widarjono, A. (2007). Ekonometrika Teori dan Aplikasi untuk Ekonomi dan Bisnis. Yogyakarta: Penerbit Ekonisia.

Wong, K.N., Tang, T.C, (2007). The effects of exchange rate variability on Malaysia's disaggregated electrical exports, Journal of Economic Studiess. 